\title{
Reconsidering the Nature of the Unconscious: A Question on Psychoanalysis in Literary Studies
}

\author{
L. Suharjanto, SJ \\ Sanata Dharma University
}

\section{Abstract}

Psychoanalysis has been used invariably in literary studies, as it helps literary interpretation to touch the often-puzzling-dimension of motives and feelings in literary works. The domination of psychoanalysis in the twentieth century, however, has been questioned with the new awareness that the unconscious mind is not innate but constructed. Such a disposition challenges not only the practice of using psychoanalysis in literary studies but also the validity of psychoanalysis itself.

Keywords: psychoanalysis, literary interpretation, awareness

\section{A. INTRODUCTION}

Since developed in Vienna in 1890s, Sigmund Freud's theory of psychoanalysis has significantly contributed to psychology, especially because of psychoanalysis's unique description of the human unconscious. For literary critics, Freud's psychoanalysis is a key to entangle the motives and feelings of the author and the characters. Barry, in his introduction to Beginning Theory, states that Freud's psychoanalysis is a useful tool for literary interpretation, especially for analyzing the puzzling elements in the literature. These elements are caused by the nature of literature itself as a body of work that does not with making direct explicit statements about life, but show and express experience through imagery, symbolism, and metaphor (Barry 102). An example Barry noted as a famous work of psychoanalysis is the interpretation of the motive for Hamlet's delay in his vengeance against his uncle. Freud, in The Interpretation of Dreams, examined Hamlet's unconscious and demonstrated that Hamlet had an Oedipus complex, i.e. the unconscious hatred to his father that he wished his father's death. What his uncle had done was precisely what Hamlet secretly wished to do himself. He delayed in executing his vengeance against his uncle because his conscience created scruples in him and cultivated in him a guilty feeling of being no better than the one he wanted to punish (Barry 106).

\section{B. DISCUSSIONS}

In America, psychoanalysis has flourished since 1909 when Freud introduced the concepts in a series of lectures at Clark University. Scholar Nancy Schnog, Pfister's coeditor of Inventing the Psychological, states that from World War II through the early 1970s, the core ideas of psychoanalysis such as repression, resistance, the centrality of sexuality, the Oedipus complex, and transference became tremendously influential within institutions of schools and universities, and gradually became the daily psychological common sense of the American middle and upper classes (Pfister 5). She says, "Parents and teachers speak knowingly of 'inferiority complexes.' The comic strips and movies refer familiarity to 'frustrations' and 
'repressions."' As Schnog shows, Freudian psychoanalysis had been long present in the media, intellectual life and artistic movements, education, pediatric advice and family counseling, mental health policy, legal processes, and military decision making (Pfister 6).

However, since Lacan, there have been questions about Freud's description of the unconscious whether the unconscious is 'prelinguistic' or a biological force prior to language. Lacan assumes that the unconscious is like a language and language is a system already complete and in existence before one enters into it. The content of the unconscious is unknowable. It is like every signified that is always lost and purloined. One can only guess at the nature of this content by observing its effect. Lacan concurs with Saussure who shows that meaning in language is matter of contrasts between words and other words, not between words and things. Then, language is detached from external reality and becomes an independent realm. One may see the endless games of signifiers in a language, as he also may see the effect of the unconscious in every action. But, one cannot come into certainty about the signified of those signifiers, just like one cannot come to the precise nature of the content of the unconscious (Barry 118). Adapting Lacan's principles to literary criticism, critics do not analyze the unconscious of the author and the characters, as in Freud did, but analyzes the text itself by uncovering the unconscious beneath the conscious of the text.

To formulate it more concisely, the question that challenges Freudian psychoanalysis is whether the human psyche is socially constructed (acquired, inscribed, and made meaningful by culture) or that it is biologically innate (biologically inherent, expressed, and intrinsically meaningful). Lacan rejects the biological dimension of Freud's concept of the unconscious. For Lacan, in this unconscious lies the true human selfhood, and hence the self is shown not as an essential entity but a linguistic effect. After Lacan, the discussion on the instability of the subject (the self) is continued. It appears in Joel Pfister's Inventing the Psychological how studies of the American history have led the scholars to conclude that the "psychological" and "emotional" are concepts constructed within culture and that psychoanalysis in America is an ideological symptom.

To explain this statement, Pfister summarizes Heelas, Kovel, and Hochschild and shows the fact that the human emotions and the category of the psychological have been understood in different way across eras and cultures. Medieval "accidie," for example, which is "the losing one's zeal for praying" expresses the Renaissance emotion of melancholy, which was then vital to describe human nature, now is not a concern in modern society. Also, it is unusual for Western culture to understand emotion the way Eastern culture understands it as "external agencies which invade or posses people." Some cultures even house the emotions in different organs such as the heart, liver, or stomach (Pfister, 22). The cultural bias seen in the concept of emotion and human psyche as Pfister has noted is a suggestion to examine further the nature of the Freudian psychoanalysis. 
Frederic Jameson, a Marxist dialectician, examines the concepts in psychoanalysis in the context of the American family transformation. He asked in 1974, "What if the Freudian raw material (...dreams, slips of the tongue, fixations, traumas, the Oedipal situation, the death wish) were itself but a sign or symptom of some vaster historical transformation?" (Jameson, in Pfister 35). This question is related to the phenomenon that many members of the American middle and upper classes have preoccupied themselves with notion of the self, the family, and the body that center on dreams, childhood conflicts, familial tensions, and ambivalence. According to Jameson, the widespread popularity of psychoanalysis in America has something to do with the isolation of sexual experience and the privatization of bourgeois families in industrial America, which spawned complex emotional relations in themselves. They turned inward and developed a cultivation of inner life through psychology. Psychoanalysis, with the oedipal narrative in it, became a historical and ideological reason in such society which was heating up emotionally and looking for therapeutic discourses as a response. Therefore, since 1970 the nineteenthcentury American white middle-class families have refined their understanding of the psychological and the emotional in terms of psychoanalysis, and with it, they have also intensified feeling of affection, guilt, and ambivalence. The twentiethcentury offspring of such families, not surprisingly, recognized and embraced psychoanalysis as universal truth (Pfister, 35-36).

To conclude these reflections let us consider a recent publication in Harvard Magazine by Ashley Pettus, "A Cultural
Symptom? Repressed Memory." This article exposes a fascinating question posed by Harrison Pope, a professor of psychiatry. Pope's research investigates whether what has been famously called "repressed memory" or "dissociative amnesia" belonged to people prior to 1800. The basic assumption is that "if dissociative amnesia were an innate capability of the brain-akin to depression, hallucinations, anxiety, and dementia- it would appear in written works throughout history" (Pettus 2008). The research shows that dissociative amnesia appeared in nineteenth-century pieces of literature; two well-known examples are A Tale of Two Cities (1859), by Charles Dickens and Captains Courageous (1896), by Rudyard Kipling, but dissociative amnesia did not appear in pre-modern sources. A \$1,000 reward had been offered to the first person who could identify a case of dissociative amnesia in any work of fiction or nonfiction prior to 1800 but no convincing examples emerged. Therefore, Pope and his colleagues concluded that "the absence of dissociative amnesia in works prior to 1800 indicates that the phenomenon is not a natural neurological function, but rather a 'cultural-bound' syndrome rooted in the nineteenth century" (Pettus 2008). The fact that the concept of dissociative amnesia solidified in the twentieth-century imagination is suspected to be enhanced by two major factors: psychoanalysis and Hollywood. Pope says, "Film is a perfect medium for the idea of repressed memory. Think of the 'flashback,' in which a whole childhood trauma is suddenly recalled. It's an ideal dramatic device" (Pettus 2008). 


\section{CONCLUSION}

In conclusion, psychoanalysis may be useful to help understand the unconscious in therapy and in literary and cultural studies. However, as I have shown, the unconscious is a construction and its content can never be known thoroughly. On one hand, the absence of the idea of repressed memory in the literature prior to 1800 shows the contingency/relativity of the unconscious as seen in psychoanalysis so far. On the other hand, it also opens a further discussion on the 'constructedness' versus the 'universality' of the unconscious itself.

\section{REFERENCES}

Barry, Peter. Beginning Theory: An Introduction to Literary and Cultural Theory. Second Edition. Manchester and New York: Manchester University Press, 2002.

Pettus, Ashley. "A Cultural Symptom? Repressed Memory." In Harvard Magazine (January-February 2008. Retrieved 7 February 2008 <http://harvardmagazine.com/200 8/01/p-repressed-memory.html>.

Pfister, Joel. Introduction. "On Conceptualizing the Cultural History of Emotional and Psychological Life in America." In Inventing the Psychological: Toward a Cultural History of Emotional Life in America. Eds. Joel Pfister and Nancy Schnog. Yale University, 1997.

Schnog, Nancy. Introduction. "On Inventing the Psychological." In Inventing the Psychological: Toward a Cultural History of Emotional Life in America. Eds. Joel Pfister and
Nancy Schnog. Yale University, 1997. 